\title{
第22回日本門脈王六進症研究会抄録
}

期 日: 平成元年 9 月 30 日
会 場 : 京王ブラザホテル
世話人 : 出月 康夫

特別講演要旨

食道静脈瘤治療の欧米の現況について

\begin{abstract}
井
口潔

第33回万国外科学会が1989年 9 月10 16日にカナダ トロント市で開かれ Portal hypertension in the nonalcoholic patient Royal free 大学の Hobbs 教授の司 会でシンボジムが行われた。その顔ぶれは次のよう であった。

Anatomy of oesophageal varices: why do they bleed? R.A.J. Spence (UK)

Solerotherapy : K.J. Paquet (Germany)

Selective shunt: I.J. Sarfeh (USA)

Japanese experience: $K$. Inokuchi, Y. Idezuki (Japan)

Managing portal venous thrombotic problems: J.

M. Hay (France)

この他にZannini(Italy)が予定されていたが，久席

の経験と硬化寮法の日本の現状を紹介され，私は選択 的シャント，とくにWarren シャントの欠点を補 万方 法としての Splenopancreatic disconnectionの重要 性を指摘した。

他の演者の論旨は、よく報告に接しているるのなの で省略するが，演者により主張の重点は異なるが，㱏 例の riskにより，また局所病変により、いくつかの治 療法を選択し，協同させるといら集学的治療の概念で は同意であった，討論の中で，日本が行った門脈圧非 减圧手術の予防的手術に関する共同研究の結果につい て Turbulanche から質疑があり，日本側はその説明を 行ったがこれは1990年 7 月の Hepatology に報告さ れたよらに非減王手術の予防的手術としての意義は決 着したものと考える。
\end{abstract} であった。日本からの報告では，出月教授は直達手術

\section{I. 胃静脈嘴の治療法}

1. 胃静脈瘤, 特に巨大 porto-systemic shunt による胃底部静脈瘤の血行動態に関する検討 藤田学園保健徫生大学消化器外科 吉松 泰彦，青木 春夫，蓮見 昭武 島建 元秀, 河田 周三, 橋村 宏一 江崎 哲史

食道静脈瘤と連続する胃噴門部静脈瘤の供給血流源 として，左胃静脈経由の門脈血流のほか，左胃動脈な どの局所流入動脈血流の関与については, かねてより 報告してきた。一方胃穹落部静脈瘤は，自然の巨大な porta-systemic shunt $の 一$ 部が静脈瘤を形成すると考 えられてきたか，局所流入動脈血す供給血流源として 関与している症例がみられた。従って手術術式として, porta-systemic shunt の遮断のみでは不充分であり，
流入動脈血 る遮断される Hassab 手術が適応とされて いたが，さらに消化管壁内副血行の遮断のため拐落部 静脈瘤より肛門側の胃離断が必要となる症例すあるこ とを報告した。

\section{2. 胃静脈瘤の内視鏡像とその治康} 国立習志野病院内科

日野 真一, 隆元 英, 神谷 尚志 五十窗正彦

内視鏡的に胃静脈癉を定義した上で，胃静脈瘤内視 鏡所見を占居部位 ( $\mathrm{L}: \mathrm{Lc}$ (噴門部), $\mathrm{Lf}$ (穹䍜部)), 形態 $(F)$, 出血関連所見 $(R)$, に分頑, 記載した。 Lc 静脈㾇は食道静脈瘤を有する例にのみ認められたが, Lf 静脈瘤は食道静脈瘤との関保が乏しかった. 上部消 化管出血例59例の内視鏡的検討を行ったところ，出血 
源が䏴静脈瘤の症例は 9 例 (15.3\%, Lc 静脈瘤 5 例, Lf 静脈瘤 4 例) で，食道静脈瘤17例，胃潰演13例に次 いで多かった。胃静脈瘤破綻例は全例，形態 $(F)$ 高度 で, そのうち Lc 静脈瘤破糘例は全例, 高度食道静脈瘤 を合併した，Lc，Lf 静脈瘤破糘例とも，SB tubeによ る一時的止血を得, Lc 静脈痛には内視鏡的食道静脈瘤 硬化療法(EIS)が著効を示した。破糘例に限らず，EIS による Lc 静脈瘤の改善を認めたが，Lf 静脈瘤の改善 は見られなかった。

\section{3. 胃静脈瘤の臨床特性と外科治痖}

広島赤十字・原爆病院外科

$\begin{array}{lrll}\text { 小川勇一郎, 由茅 } & \text { 宏文, 佐々木幸治 } \\ \text { 永島 明, 福田 } & \text { 篤志, 川野 亮 } \\ \text { 林 貴史, 柴田 } & \text { 憲助, 田中 真二 }\end{array}$

当科において過去20年間に手術された食道胃静脈瘤 192例を，I 群 (静脈瘤が食道に限局) 111例，II群（静 脈瘤が食道と胃の両方に存在）72例，III群（静脈瘤が 胃に限局）9例の 3 群に分類して各種の比較検討を 行った，年龄，性別，基礎疾患，Child 分類別頻度は各 群注涪同様であったが, ICG $\left(\mathrm{R}_{15} \cdot \mathrm{K}\right)$ はIII群がゃや 良好であり，門脈圧は山群が有意に低かった。副血行 路パターンはI，II群では左胃静脈優勢例が最も多く， III群では最も少なかった，出血の頻度は各群ともほぼ 同様であったが，III群では緊急手術の頻度が高く，手 術成績は食道静脈瘤より胃静脈瘤の方が有意に良好で あった。

\section{4. 胃静脈瘤の治療法}

慶応義塾大学外科

宮澤 光男, 都築 俊治, 上田 政和 新井 洋明, 田辺稳，飯尾宏 木原 康裕, 清水 壮一, 阿部 令彦

1989年 7 月までに当科で経験した食道・胃静脈瘤は 221例で，そのうち胃静脈瘤を認めた症例は55例であっ た。胃静脈瘤が食道静脈瘤より優位であった症例は 27 例であり，その27例につき治療法と予後を検討した． 治療法は, Hassab 手術12例。 Hassab +食道離断術 （TR） 3 例, 释回盲静脈的静脈瘁塞拴術（TIO）11例， TIO+Hassab+TR 1 例であった. 全例胃静脈瘤に対 する効果を認めたが，残存，再発食道静脈瘤に対して は内視鏡的硬化療法を追加した. 再吐血率は TIO 症例 が40\%, Hassab 症例が20\%であったが，食道離断術施 行例では再叶血はなかった，TIO および Hassab 施行
後には内視鏡的検查によって食道・胃静脈瘤の消長を 観察し，適宜硬化療法，食道離断術を付加する必要か; あると考えられた。

5. 治療法からみた胃静脈瘤の消長一とくに食 道静脈瘤併存例を中心に一 日本医科大学第 1 外科

真々田裕宏, 恩田 昌彦, 田尻孝 梅原 松臣, 吉田 寛, 山下 精彦 金徳栄，解淳，足立 幹夫 鳥羽 昌仁, 向東

目的：胃・食道静脈瘤併存患者に対する各治療法の 消失効果とその持続性の検討.

対象と方法：1976年 1月か5 室に入院し治療をおこなった食道静脈瘵患者352例中， 経過を拉えた胃静脈瘤併存例88例を対象とした。

成績：胃静脈瘤消失率は，手術療法では食道離断術 $83.9 \%$, DSRS $100 \%$ ，塞栓術では, EE 単独, $84.6 \%$, PTO, TIO 単独 $50.0 \%$, PTO, TIO+SAEorLGE $69.2 \%$ ，EE と他塞栓術併施100\%であった，持続率で ๖ DSRS 括よび $\mathrm{EE}$ と他塞栓訹併施例が有意に高 かった.

結語：胃，食道静脈留に対する治療法として，手徠 療法ではシャント手術が，保存療法では EE と他塞栓 術併施例が有効であった。

\section{6. 胃静脈瘤の治療法}

杏林大学第 2 外科

小林摮, 鍋谷 欣市, 花阔 建夫
小野澤君夫, 中田 芳孝

過去16年間に当科に入院した食道胃静脈瘤症例は90 例である。この内胃静脈瘤を認めた症例は20例 (22.2\%)であった，食道静脈瘤合併例13例，胃静脈瘠 のみのもの 7 例であった，手術は，胃静脈瘤20例中 18 例(90.0\%)に行った，手術方法は，経腹的に，(I) 胃 上部切除術 2 例 (11.1\%)，〔II] Hassab 手術 4 例 (22.2\%)，〔III]食道離断及び穹阵部切除術を12例 （66.7\%）に行った。〔III]の手術理由は，胃静脈瘤か， 特に穹蕯部主体である場合，穹隆部の胃壁が非常に薄 く，胃壁全体が静脈瘤様となっており，Hassab 手術の みでは，どらしても胃壁内倒副血行路の郭清が不充分 と思われる。このため, 静脈瘤の完全郭清を目的とし て，下部食道胃上部血行郭清街に加えて，症例に上っ て，穹㢈部切除術に，食道離断を行ら方法が良いと考 
える。

\section{7. 胃静脈痛における新しい治療法}

愛知医科大学第 1 外科

長谷川 誠

胃静眽瘤は食道静脈瘤に合併する頻度が高く，しば しば大出血を来し治療に難涉する病態である。

数室では，在来実施して来た胃上部切除術を、自動 吻合器の導入で手術時問を短箱し，適応範囲を広げ 行っている.

最近の 6 年間に胃静脈瘤出血を来し手術を施行した 症例は 5 例であり，そのうち 4 例が旰硬变症例であり， 他の 1 例は肝外門脈閉塞症例であった。一方, 手街不 能となった症例は 5 例であり, 肝不全への移行, 進行 した訮癌の合併が認められた。

手街は, 脾摘, 血行郭清, 胃上部切除術の後, 食道 胃端側吻合術を自動吻合器によって行っている。

今回, これら手術症例の動向, 術式の改善に付いて 報告する。

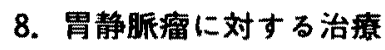

富山医科菜科大学第 2 外科

鈴木修一郎, 桐山誠一,山田明

島崎 邦彦, 山岸 文範, 白畸 功

霜田 光義, 田沢 賢次, 藤巻 雅夫

96例の食道胃静脈溜について千葉大第 1 内科渡辺の 分類に基つき検討し以下の結論を得た. 1. $68.9 \%$ 症 例に胃静脈瘤を認めた。 2. 胃静脈瘤(サ)では40\%に, (卅)では全例に胃留短絡路を認めた。3．胃静脈瘤 $(+)$ では手術例，Hassab手術一硬化療法併用療法では $100 \%$ ，硬化療法例では86.3\%に胃静眽樒に対する治 療効果を認めた。 4. 胃静脈渨 (サ) では手術併用療法 では全例にその治療効果を認めたが硬化療法の 2 例は 何れる效果がられなかった.5. 胃静脈瘤出血例 6 例 の内 1 例が胃静脈痹 (\#)，5例が（卅）であった。6. 胃静脈瘤出血に対する治療は胃静脈留（十）では硬化 療法を、(H)，(卅)では高頻度に胃祭短絡路を有する ことより，現状では手術を行ら方針である。

\section{9. 胃静脈瘦に対する治癔法の選択について 東京女子医科大学附属第 2 病院外科 \\ 石川 信也，成高 義彦，芳賀 酸介 矢川 裕一, 平井 雅倫, 島川武 大石 俗典, 菊池 友允, 小川 健治 暒原 哲郎}

当科にて 8 年 9 力月間に経験した胃静脈瘤治療数は 28例で，食道胃静脈䈏症例数の10.6\%(Lc+Lf) であ る. らちわけは, Child 分類では, A 2 例, B 14例, C 12例であった，胃静脈瘤手街成績をみると緊急手術 は，待期手術に比較し，明らかに予後不良であった。 緊急手術で死亡した 5 例は．いずれる Child C の症例 であり，緊急手術とChild Cが重なると予後が極めて 悪かった．そこでこの予後不良な緊急手術をさけるべ き治療法として, Histoacryl による内視鏡的硬化療法 を試み，有効な止血効果が得られた，今後，䇣急手術 を回避すべき新しい手段とし，定例教を重ねていきた いと考えている.

\section{0. 胃静脈瘦破裂の治療}

東京大学医学部第 2 外科

$$
\begin{aligned}
& \text { 大橋 一雅, 三條 健昌, 野村 幸博 } \\
& \text { 今村 宏, 皆川 正己, 橋本 雅司 } \\
& \text { 柴崎 正幸, 大友裕美子, 川崎 誠治 } \\
& \text { 出月 康夫 }
\end{aligned}
$$

当科にて1964年より1989年 6 月まで治療した食道胃 静脈瘤は629症例である. 胃静脈瘤所見の有無に関し て、記載の明確な症例493例を対象として検討したとこ 万, 食道静脈瘤単独のもの181例, 胃静脈瘤単独のもの 7 例, 食道胃静脈瘤に胃静脈瘤の合併したもの305例で あった。緊急内視鏡検查の行われた昭和47年上り経験 した繁急出血例の検討で，出血部位の確認できた食道 胃静脈瘤合併症例は16例あり，之の内食道静脈瘤破裂 は10例であり，胃静脈瘤破裂は6 例であった。胃静脈 㿑破裂例の治療法は東大第 2 外科法 2 例, Hassab 手 術 2 例, PTO 1 例, 保存的療法 1 例であった。教室で の症例を中心に胃静脈瘤出血の治療法について検討し た.

\section{1・胃静脈瘭出血に対するPTOの治療成績の 検討 \\ 千葉大学第 1 内科 \\ 古瀬 純司, 松谷 正一, 大藤 正雄 千葉社会保険病院村邦夫}

大量出血をきたすことの多い胃噴門部から穹篷部に 及ふ発達した孤立性胃静脈瘤に対する PTOの治療効 果につき検討を行った。

対象は胃静脈瘤出血をきたしたLC 9 例，IPH 2 例、計11例である.これら11例の PTP 所見では胃留短 絡を中心とした著明に発達した門脈大循環短絡を全例 
に認めた．塞栓は11例中10例に可能であり，側副血行 路の全ての塞栓化が 6 例 (54.5\%) に可能であった。 止血効果は10例中 9 例 ( $90 \%$ ) に認められ, PTOによ り胃静脈瘤出血の高率な止血効果が得られた。内視鏡 所見の検討では PTO 前後で胃静脈瘤の形態上の改善 は 4 例（40\%）に認めた。再出血は 9 例中 5 例にみら れ, 不完全塞栓例之Child Cの肝機能不良例であった。 以上, PTOに上り胃静脈瘤出血の止血が高率に得られ たが，長期止血効果の維持には他の追加治療が必要と 思われた。

\section{2. 胃静脈瘤に対する硬化療法の治療経験} 昭和大学藤

$$
\begin{aligned}
& \text { 鈴木 悟司, 高棉 寞, 杉山 圭一 } \\
& \text { 光銭 健三，関 盛化，佐竹 儀治 } \\
& \text { 藤田 力也，菅田 文夫 }
\end{aligned}
$$

1989年 6 月までに当院にて施行した胃静脈瘤への硬 化療法は, 噴門部静脈瘤 5 例と穹落部の孤立性胃静脈 瘤 3 例の 8 例である。症例は男性 5 例，女性 3 例であ り, 年齢は，29〜77歳（平均53.6歳）であった。硬化 剂は， $3 \%$ Polidocanol $と 50 \%$ Glucose $の$ 等量混合液 で静脈瘤近傍の粘膜下に注入した。注入量は 1 回の穿 刺で3〜 $5 \mathrm{~m} l$ で, 1 度の治療で 3 から 4 力所に注入し, 計 $15 \sim 40 \mathrm{~m} l$ を注入した。一明止血は 8 例全例に成功 し， 7 例で静脈瘤の消失を認めたか，消失困難であっ た 1 例は経過中に大量出血を来し死亡した，粘膜下注 入法による硬化療法は, 血行動態に関保なく安全に施 行できた良好な止血効果を得られ，全身状態不良例で の1st choice と考克られる。

\section{3. 胃静脈瘤に対する造影下内視鏡的硬化療法 （直接穿刺法）の検討}

\section{奈良県立医科大学第 3 内科}

小泉 雅紀, 松本 雅彦, 本田 泰啓
小嶌 秀之, 森本 昌史, 長本 一成
吉治 七志, 喜多 公雄, 北野 浩行
松本 昌美, 福井 博, 辻井 正

食道静脈瘤に対する内視鏡的硬化㞠法 (EIS) を施行 した. 186例の予後検討から，胃静脈瘤出血に対する積 極的な対策の必要性が示唆された。をこで胃静脈瘤出 血の 2 例および食道静脈瘤に対する EIS 後胃静脈瘤 出血が懸念された 9 例を対象とし, 胃静脈瘤に対し直 接穿刺法による造影下 EIS を試みた。穿刺部出血は軽

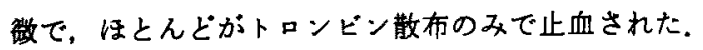

出血例の 1 例は止血不能であったが，他はいすれれる静 脈瘤の消失または縮小を認め，経過は良好であった。 一過性の血压低下を 1 例に認めたが，他に重篤な合併 症は認めなかった，以上，本法は安全かつ有効であり， 今後とも試みるべき治療法と考える.

\section{4. 胃静脈瘤破裂の治療法}

埼玉医科大学第 1 外科

駒崎 敏郎，山崎 達雄，鉫柄 稔

松本隆, 小山勇, 尾本良三

教室では過去 3 年間に 3 例の胃静脈溜出血に対し て，内視鏡的硬化療法を行ったが，いずれも止血不能 であった，肝癌合併の 1 例に対しては，PTOにて止血 し得た。他の 2 例においては, 肝機能良好であったた め Hassab 手衍を施行して止血し得た。

胃静脈瘤に対する硬化療法は，ガイドチューブ，口 側バルーンが使克ないこと，反転して穿刺しなければ ならず，穿刺部を直接圧迫しつららいこなど，食道静 脈瘦に対する硬化療法と比へて，手技的に異なる点が ある.

Hassab 手術は胃静脈瘤破裂において有効であり， 肝機能良好例で他の治㞠法で止血不能である場合に は，時機を逸することなく行われるべき治療であり， PTO も試みられるべき治療法であると思われた。

\section{5. 胃静脈瘤出血例の治療法一特に硬化療法の} 意義について一

久留米大学第 2 内科

井上林太郎，高木 孝輔，角野 通弘

大久保和典, 永田一良, 江口敏

豊永 純, 谷川 久一

1980年 6 月から1989年 5 月までに当救命救急セン ターに搬入された門脈王六進症を伴う上部消化管出血 は352例である。この内，胃静脈瘤出血は20例(5.7\%) で，その内視鏡所見，門脈造影所見及び治療成績につ いて検討した。胃静脈瘤出血20例のうち EIS のみで止 血できたのは15例(75\%)で，更に 2 例に Hassab 手術 を施行し，合計18例（90\%）で止血に成功した，最長 6.5年の観察期間中再出血したのは軽快退院した13例 中 2 例のみで, 胃静脈瘤出血に対する EIS の有用性が 示唆された. また, EIS 不成功例では術後潰場からの出 血例が多く，血管内注入を心がけること，また EISに て止血不能で肝機能良好な症例性，外科的治療を考慮 することが必要と思わた。 


\section{6. 胃静脈瘦出血に対する硬化療法の検討} 福島県立医科大学第 2 内科

小原 勝敏, 大柳 裕登, 桑名 俊光
平原 美孝, 坂本 弘明, 森藤 隆夫
粕川 禮司

胃静脈瘁 $(\mathrm{Lg})$ 61例の硬化療法（ST）の成績から， Lg 出血例に対する治療法の選択につき検討した， Lg の頻度は29.5\%で，そのうち食道静脈瘤 (EV) と交通 のある例は X 線透視下に食道側からの EOI 逆流によ

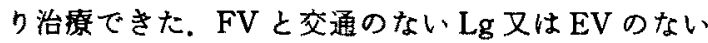
$\mathrm{Lg}$ (孤立性 $\mathrm{Lg}$ ）15例に対し， Lg を直接穿刺 L X 線透 視下にEOI を注入する方法では，有効率が46.7\% と低 い. EOI 法無効 Lg 出血 6 例に, $\alpha$-cyanoacrylate monomera (CA) によるSTを行い全例瞬時に止血し えた。孤立性 Lg 出血に対する治療は，可能なら手術を 優先し，そらでなければSTに頼らざるを得ないＳT 前のイオパミドールによる Lg 直接造影所見が重要 で，Lgの造影が良好なら EOI 法の効果が期待できる が，不良な場合はEOI 法は無効でCA 法が有用であ る.

\section{Histoacryl を用いた内視鏡的硬化療法の} 意義一胃静脈瘤の治療を中心として一 東京慈恵会医科大学青戸病院外科学教室 山本 学, 青木 哲, 千葉井基泰
一志 公夫, 大西 健夫, 三穂 乙實 同内視鏡科 鈴木 博昭

胃静脈瘤の緊急出血例では緊急手術は回避すべきで あり，内視鏡的硬化療法を中心とした非観血的な一時 止血法が重要である。我々は従来から行っている1\% AS の血管内外併用注入法に加え，このような出血の コントロールを目的として，昨年 2 月に Histoacryl を 用いた硬化療法を導入した。治療症例は胃静脈瘤 5 例 と食道静脈瘤の早期頻回出血 1 例であり，全例に良好 な止血効果を得た。今回は緊急止血々静脈瘤の消失を 目的に 2 回の治療を行い, 長期に経過観察中の胃静脈 瘤例（63歳男，Child B）について報告した。本例は内 視鏡観察中に Histoacryl のボリマーが排泄され，脱落 後の出血もなく胃静脈瘦は消失した.

\section{8. 胃静脈瘤に対する内視鏡的硬化療法の検討 京都府立矤科大学第 3 内科}

岡野均, 児玉 正, 过秀治

藤野 博也, 福光 真二, 道中智恵美

寺前 直樹, 加嶋 敬

見在までに胃静脈瘤に対する直接硬化療法施行症例 数は19例である.硬化療法の手技はすでに報告した食 道静脈瘤硬化寮法に準し，エトキシスクレロール液の 血管内注入法で行ったが，最近経験した2例では，組 織接着剂である Histoacryl ${ }^{\circledR}$ blue を硬化剂として用 いた．内訳は緊急出血18例，待期 1 例である. 緊急出 血18例の5ち 7 例は食道静脈瘤硬化療法後例であっ た。緊急出血18例のらち16例はエトキシスクレロール， 残り 2 例は Histoacryl blue にて硬化燎法を行い, 全例に一時止血を得た。一部の症例ではその後の追加 硬化療法により静脈瘤形態の改善も同時に得られた。

胃静脈瘤出血に対してまず硬化療法にて止血をはか り，その後待期手術を行うべきと考えるが，手術不能 例で再出血の危険がある時は硬化療法のみでも有効な 治療法と考之られた。

\section{9, 胃静脈瘤の治療法}

\section{日本大学第 1 外科}

$\begin{array}{lllll}\text { 亿木 } & \text { 基裕, 大野 } & \text { 諴, 岩瀬 } & \text { 正明 } \\ \text { 増田 } & \text { 勝彦, 遠藤 } & \text { 潔, 水野 } & \text { 敏彦 } \\ \text { 黒須 } & \text { 康彦, 森田 } & \text { 建 } & & \end{array}$

対象と方法：当教室にて1989年 5 月までに治寮を 行った食道静脈瘤患者は92例で，それらをI 群：43例 （胃静脈瘤を合併するもの），II群：3 例（胃静脈瘤単 独）に分け各種治療成績について検討した。I 群では 手術療法15例(胃上切： 5 例，DSRS 4 例，Hassab 手 術 5 例，食道離断術 2 例)に，保存療法は28例で TIO+ $\mathrm{E} \cdot \mathrm{E}: 20$ 例， $\mathrm{E} \cdot \mathrm{E}$ 単独：8 例であった。II群では全 例に手術療法 (Hassab 手術 2 例, 胃上切 1 例) が施行 された。

成績：(1) I 群では保存療法にて供給路としての Lg の消失率は $89 \%$ で， $\mathrm{TIO}+\mathrm{E} \cdot \mathrm{E}$ 施行例では20例中20例 (100\%) 消失を認め, E·E 単独では 8 例中 6 例 $(75 \%)$ の消失を認めた。（2) I，II群とも手術療法が施行され た18例中18例（100\%）に Lg の消失を認めた。

20. 摘脾にて止血し得た局所性門脈圧六進症に よ了胃癌根治術後残胃静脈嘴の 1 例 大阪回生病院外科

川上 克彦, 岡部 靖彦, 岩本 拓也

滰口哲, 渡辺清朗

症例は76歳男性，前庭部進行胃癌のため胃覀全摘， 
リンパ郭清術を受け, 術後 2 年 1 カ月, 下血にて来院. 内視鏡では中部食道以下に軽度の静脈瘤と残胃の著明 な静脈瘤を認めた $\left(\mathrm{CW}, \mathrm{RC} \oplus, \mathrm{F}_{1}, \mathrm{Lm}-\mathrm{g}, \mathrm{Fo}\right) . \mathrm{PTP}$ では脾静脈中部の閉塞があり，同部肝側の門脈王は正 常であった。術直前の選択的脾動脈造影静脈相では脾 門部短胃静脈瘤と残胃大弯側に特に著しい静脈瘤を認 めた．局所性門立症による残胃静脈瘤出血の診断の下 に造影用バルーンカテーテルを脾動脈内に留置し，術 中出血量を制御し摘脾術のみを施行した。術後下血は なく，内視鏡的に食道胃静脈瘤の消失と残胃の阻血性 変化のないことを確認した，本症に対するPTP と術 直前動脈造影用バルーン留置下の摘脾術の有用性を認 めた。

\section{1. 頻回の硬化療法後, Hassab 手術が有効で} あった胃静脈瘤の 1 例

昭和大学藤が丘病院外科 ${ }^{12}$, 内科 ${ }^{21}$

浜井 直人, 生田目公夫, 中村 豊英
中野 浩, 幕内 幹男, 池田 忠明
鈴木 快輔", 鈴木 悟司, 高橋、寛
藤田 力也 力 $^{23}$

近年食道静脈瘤に対しての内視鏡的硬化療法はほぼ 確立されてきたが，胃静脈瘤に対する硬化療法は，い まだ解決すべき点が，残されている．今回我々は頻回 の硬化療法が無効であった胃静脈瘤に対し Hassab 手 術を施行し良好な結果を得た。症例は46歳男性，フル ロール性肝硬変症にて経過観察中に吐血し内視鏡的硬 化療法にて一時的に止血したが静脈瘤は消失せず，再 出血をきたした。手術後静脈溜は減弱し，良好な結果 を得た。胃静脈瘤に対しての硬化療法は，胃噴門部に 限局したものに対しては有効であるが，胃底部に及ぶ るのでは手術が第一選択であると思われる。

\section{2. 胃静脈瘤に対する超選択的遠位脾堅静脈吻 合術の治療成績}

北海道大学第 2 外科

中島 公博, 加藤 紿之, 深山 雅寿

奥芝 俊一，児嶋 哲文，下沢 英二

田辺 達三

当科では1981年より門脈圧え進症に対する術式と乙 $\tau$, Spleno-pancreatic disconnection（SPD）を伴 5 選択的遠位脾腎静脈吻合術を行っている。しかし同手 街施行例中，遠隔時に胃上部静脈瘠を形成する症例が 散見されたため胃小弯側の血管郭清に加え胃上部浆膜
筋層の切離再縫合を付加する超選択的遠位脾腎静脈吻 合術を確立した。本術式を施行した食道・胃静脈瘤20 例中再吐血を来したのは早期の不充分な血行郭清を 行った 1 例のみであり極めて良好な予後が得られた。 ま大術前後の血管造影所見より本術式は食道・胃上部 の選択的減圧が可能であり，食道静脈㿔のみならず胃 静脈が顕著な症例にも極めて有効であると考えられ た.

\section{3. 胃静脈瘤に対する直達手術の検討}

\section{名古屋大学第 2 外科}

原田 明生, 小林 裕幸, 野浪 敏明

岸本 若彦，木村 保則，春日 輝明

加藤 秀幸, 一色 浩一，伊藤 隆文

黑川 剛, 竹田 伸, 氏田 剛

沈世強，中尾 昭公，高木 胎

最近10年間に経験した食道または胃静脈瘤 227 症例 を内視鏡による静脈瘤の主な存在部位により $\mathrm{EV}$ 群 (184例)，EGV 群 (33例)，および GV 群 (10例) に分 類して検討した.EGV 群は比較的高度肝障害例を多く 認め，GV 群では高齢者，肝癌併存例が多くまた門脈 王，脾重量は他群に比べて低值であった，治療として EGV 群の手術適応症例には胃上部切除術を, 手術不能 例には硬化爒法が有效であった。一方 GV 群に対して は手術適応症例には胃上部切除術を第一選択とし, 肝 機能高度障害例には脾摘・血行郭清術を行 と考えられた。

\section{4. 食道静脈瘤を有しない胃静脈瘤に対する外 科療法の検討}

岐阜大学第 1 外科

宮本 康二, 鬼束 惊義, 渡辺 敬

後藤 全宏, 日野 晃紹，尾関 豊

林 勝知, 厇瀬 一

近年食道静脈瘤に対する治療は内視鏡的硬化療法が 主体となり外科的療法を施行する機会は減少してき た，しかし胃静脈瘤に対しては内視鏡的硬化療法の評 価も一定して扣らず外科的療法を施行する機会す多 い.今回我々は食道静脈瘤を伴わない胃静脈瘤症例に 対する外科的療法について検討を加えたので報告す る。症例は 6 例であり，これらは食道及び胃静脈瘤全 症例の $2.25 \%$ であった，年龄は39歳から68歳までで男 性 4 例，女性 2 例，原疾患快肝硬変 3 例，慢性肝炎 2 例，脺炎 1 例であった。これらに傍食道及び傍胃血行 
遮断術を施行したところ，1例のみに胃静脈瘤再発を 認めたが，全例に胃静脈㢞の改善を認め出血をきたさ なかった。

\section{5. 胃静脈瘦に於ける Hassab 術式の検討} 順天堂大学第 2 外科

$$
\begin{array}{ll}
\text { 木下 柴一, 吉岡 知已, 丸山 俊朗 } \\
\text { 大浦 慎祐, 平出 康隆, 二川 俊二 }
\end{array}
$$

1979年 9 月より1988年 9 月迄当科に於いて行った直 達手術は457例である，そのうちわけは経胸離断術 364 例, Hassab 手術 53 例, 経腹離断術 39 例, 胃全摘下部血 行遮断術 1 例であった，Hassab 手術は胃静脈瘤に対 してはきわめて有効であった．しかし食道胃静脈瘤に 対しては下部食道に限局したごく軽度の症例にしか效 果がなかった。充た胃底部にみられる静脈瘤は S-R shuntによる血流が豊富なため硬化療法やPTOに上 る治療は困難で早期に Hassab 手術を行らべきである と考えられた，Hassab手術は肝䁍に及ばす影響はは とんどなく，特に非硬变例では肝機能改善傾向を認め た.

\section{6. 胃静脈瘦32手術例の検討}

\section{東北大学第 1 外科}

菅野 明弘, 大内 清昭, 松野 正紀

過去 10 年間の当教室における胃静脈瘤症例に対する 手術例は32例であった，基碟疾患別症例数は肝硬変症 22例, 特発性門脈圧六進症 7 例, 肝外門脈閉塞症 3 例 であった。術式は経胸的食道離断術 6 例, 胃上部血管 郭清を中心とした手術21例，その他の術式を採用した のが 5 例であった。手術時期は, 祭急手術 4 例, 待期 手術21例, 予防手術 7 例で, 直死例は緊急手術を施行 した 2 例であった，遠隔死亡例は肝硬変症の 8 例で, 死因は肝不全, 肝癌, 他荿器癌で, 再出血に上る死亡 例は認めなかった，胃静脈瘤に対する手術の直接効果 を，内視鏡所見で評価した結果，胃上部血管郭清術を 中心とした術式が優れていたか，経胸的食道離断術も ある程度の効果を有していた，胃静脈瘤には無効な例 もあり注意を要するが，食道静脈瘤合併例には有用と 思われた。

\section{7. 胃静脈瘤に対する直達手術の成績} 岩手医科大学第 1 外科

渡辺 正繁, 中村 隆二，西成尚人 杉村 好彦, 菊地充, 松野伸哉
佐藤 武彦, 佐々木 章, 斉藤 和好 昭和61年以後の食道・胃静脈瘤直達手術症例72例中 食道静脈瘤単独の12例を除く，60例を対象とした，胃 静脈瘤の形態は $F_{1}$ 16例, $F_{2} 24$ 例, $F_{3} 20$ 例で, 部位 は噴門近傍の, 小弯48例, 大弯 (Fornix) 5例. 入口 部全体 7 例であった。術式別の術後残存率は, 開胸・ 開腹の中・下部食道・胃上部血行郭清の場合, 離断兼 術中硬化療法22例中 2 例, Fundic patch 法応用の離断 7 例中 1 例, EEA 離断19例中 1 例で, 開腹の場合, 下 部食道・胃上部血行郭清兼 EEA 離断 7 例中 1 例, Has$\mathrm{sab}$ 手術 4 例中 3 例で, さらに開胸のみの中・下部食道 血行郭清兼離断では 1 例中 1 例であった。 うち $\mathrm{F}_{2}$ 以上 の残存は, 開腹の EEA 離断の 1 例, Hassab 手術の 2 例, 開胸のみの離断の 1 例に認められた。

\section{8. 救命し得た胃静脈痁破裂の 1 治験例 日本大学医学部第 3 外科}

$\begin{array}{lrrr}\text { 西村 曜, 村山 } & \text { 公, 佐藤 } & \text { 博信 } \\ \text { 吉永 学, 佐和 } \text { 尚信, 今井 滋 } \\ \text { 檜垣 } \\ \text { 時夫, 田中 和彦, 松下 恒義 } \\ \text { 田中 隆 }\end{array}$

胃静脈瘤破裂は硬化療法のみの治療では止血困難な 事が多く，緊急手術となる症例が多い.しかし肝硬変 患者に対し直達手術，シャント手術などは手術侵襲が 大きく術死する率も高い，今回我々は救命し得た胃静 脈瘤破裂の 1 治験例について報告する．症例は 54 歳男 性某医に肝硬变症で加寮中昍下血にて受診し当院に転 送される.入院後の緊急内視鏡では食道静脈瘤のほか に胃静脈瘤からの Bleeding jet が確認され, 胃静脈瘤 に対し硬化療法を施行後, S-B tubeに上る王迫止血を 行った後, 緊急手術を施行. 手術は胃切開による結禁 止血に加之, 胃冠状静脈への直接硬化療法を行った. 術後は食道静脈瘤に対し内視鏡的硬化療法を行い, 衍 後42日目に軽快退院した。

\section{9. 胃静脈瘤に対放治療法} 兵庫医科大学第 1 外科 中井謙之, 岡本 英三, 豊坂 昭弘 富本喜文, 古川一隆, 井上晃男 大阪第 2 警察病院外科朱明義 当教室において過去 9 年間に, 胃静脈瘤42症例に対 し 50\%Glucose・1\%AS・Thrombin を用いた内視鏡 的硬化療法を 32 例，硬化療法後待期手術 5 例（食道離 断 3 例 - 噴門部胃切 2 例 - Hassab 手術 1 例), 緊急手 
術 1 例 (噴切), Hassab 手術を 4 例に施行している. $\mathrm{RC}(+)$ 食道静脈瘤合併は26例で内 21 例が食道静脈瘤 硬化療法後である. RC ( - ) 食道静脈瘤合併は 8 例, 胃静脈瘤単独は 8 例である。緊急例に対しては硬化療 法を第一選択としており 34例中29例（85.3\%）に止血 を得ているが，胃穹隆部孤立性静脈瘤や胃腎シャント 形成例では無効例があり手術の適応で，当教室では通 常の Hassab 手術後, 術中内視鏡を用いて徹底した血 行郭清を施行し静脈瘤の完全消失を得ている。

\section{0. 胃静脈瘦に対する治療法の検討}

東京慈恵会医科大学第 2 外科 佐野 勝英

教室で経験した胃静脈瘤症例は, 過去10年間で141例
で，教室分類では G-I 75，G-II 41，G-III 25例で出血 例は各々 $3 ， 12,15$ 例であった. 原疾患では L.C は G.I 例が多く, 肝前性門脈閉塞例は全例 G-III 例であった。 出血の主因は静脈瘤被覆粘膜の急性潰瘍性病変である と考点，保存的療法として $\mathrm{H}_{2} \mathrm{~b}$-ant を使用している. 手術適応は主に G.III 症例, 出血例に対し行っている か，出血例では緊急 EIS を16例に行ったが，長期止血 例はなく， Linton tubeにて一時止血後の早期手術例 に良好な予後が得られた。食道静脈瘤を伴ら例では， 直達手術に伴う血管郭清で対処できるが，胃静脈瘤を 主とする G-III 症例に対してHassab 变法手術, 遠位 脾腎静脈吻合術を施行している.

\section{II. 血行動態の検査方法と治療上の意義}

\section{1. 経脾的 RI 門脈造影 (SSP) による血行動態 の評価と治療上の意義}

日本医科大学第 1 外科

$\begin{array}{lrrr}\text { 吉田 } & \text { 寛, 恩田 昌彦, 田层 孝 } \\ \text { 梅原 } & \text { 松臣, 真々田裕宏, 山下 } & \text { 精彦 } \\ \text { 金 徳栄, 鄭 } \quad \text { 淳, 足立 } & \text { 幹夫 } \\ \text { 鳥羽 } & \text { 昌化, 西久保秀紀 } & \end{array}$

目的：SSP 画像処理による, 内視鏡所見，肝機能， 吐血歴, 治療前後の变化の比較検討.

対象と方法：対象は教室でSSPを施行した未治療 の食道静脈瘤患者93例. SSP 画像より, 冠状静脈出現 率 $(\mathrm{CV} \%)=$ [胃冠状静脈 count $/($ 胃冠状静脈 + 門脈 $)$ count $] \times 100 \%$ を算出。

成績：CV\%は，(1) Child A が B，Cに比し有意に低 かった。 (2)吐血歷有無に有意差(一), (3) $\mathrm{Cw}$ が $\mathrm{C}_{\mathrm{B}}$ K比 ᄂ, $\mathrm{F}_{1}$ か⿱ $\mathrm{F}_{2}, \mathrm{~F}_{3}$ K比し, Li かi $\mathrm{Lm}$ に比し, Lm かi Ls に比し有意に低かった， RC (-)と RC (3+) に有意 差(一), (4)静脈瘤, 肝機能改善に伴い.CV\%の低下を 認めた。

結語：(1)高度静脈瘤症例, 肝機能悪化症例では, 各々 CV\%が高かった（2) SSP は治療効果の経過観察にも 有用であった。

\section{2. 胃静脈瘤の血行動態よりみた硬化療法の効 果}

兵庫医科大学第 2 外科 福田 正春, 芦田
寺方 聡一, 西岡 昭彦, 橋本 直樹 琴浦 義尚, 石川 羊男, 宇都宮譲二 当教室に括ける門脈王六進症症例377例のらち穹隆 部型胃静脈瘤16例について, 硬化療法 (ST) の治療効 果に関して, 胃静脈瘤の血行動態一特に胃腎短絡路 一について検討した。

急性出血 7 例のうち 5 例に対してSTによる止血を 試み 4 例で成功した。無効例は，Hassab 手術にて止血 したが，手術時に巨大な胃腎短絡路を認めた。

又,血管造影にて胃腎短絡路を認めたグループでは, STによる止血無効例があった。

窎湴部型胃静脈瘤に対するST の治療効果は，胃腎 短絡路の存在の有無に左右される可能性がある.

33. 粘膜保存胃離断術の胃壁内微小循環動態異 常に对する治療意義に関する血行動態的検討 藤田学園保健语生大学消化器外科

河田 周三, 青木 春夫, 蓮見 昭武

島津 元秀, 吉松 泰彦, 小森 義之

橋村 宏一, 鉿木 治郎

食道胃静脈瘤をともなう門脈王六進症に対する粘膜 保存胃離断術施行症例を対象として，術中の胃壁酸素 飽和度, 及び術前後の内視鏡的胃壁組織血流量を測定 し, 本術式の胃壁内微小循環動態異常の病態に対する 治療意義について検討した。脾摘を含む広範血管郭 清・胃離断操作を加光た胃体上部では，手術終了時の 胃壁酸素飽和度は約 $20 \%$ 减少し，末た術後長期にわ たって粘膜下組織血流量は約 $12 \%$ の減少が維持されて 
括り，従って本術式が遠肝性副血行路遮断とともに， 胃壁内㣪小㣪動態異常の病態に対してる粘膜下 AVA 释由の流入動脈血流量の減少による局所の循瓄 六准状態を解消させ，静脈瘤発症機序に合致した合理 的な治療となっていることが確認された。

\section{4. 食道静脈㿔術後循罟動態の推移}

岩手医科大学第 1 外科

松野 伸哉, 渡辺 正敏, 传藤 信博

中村 隆二, 西成 尚人, 杉村 好彦

菊地 充, 斎藤 和好

門脈殴亢進症では，全身循環え進状態を示す場合が 多い. 今回, 食道静脈瘤手術症例17例(肝硬変症13例, IPH 4 例）において術前後の全身循環動態を,SwanGanz Catheter を用いて測定し検討したので報告す ろ.

肝硬変症をICG-R ${ }_{15}$ が40\%未満の A 群と40\%以上 のB 群に分け，術前から術後 4 病日までの心保数，全 末梢血管抵抗を算出した。保数は，B 群で術後 2 病 日まで A 群, IPH 群に比べ高值で推移する㑯向を示し たか，逆に 3 病日でB群 $4.50 \pm 0.69$, に対しA 群

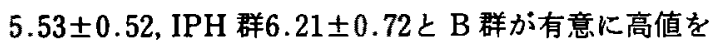
示した，全末梢血管抵抗は，各群で漸减傾向を術後 4 病日まで認めた。

\section{5. 肝硬变症における全身血行動態の特幑とそ} の意義

$$
\begin{array}{ccccc}
\text { 名古屋大学第 } 2 \text { 外科 } & & & \\
\text { 野浪 } & \text { 敏明, 黑川 } & \text { 朋, 伊藤 } & \text { 隆文 } \\
\text { 氏田 } & \text { 用, 小林 } & \text { 裕幸, 原田 } & \text { 明生 } \\
\text { 中尾 } & \text { 昭公, 高木 } & \text { 弘 } & &
\end{array}
$$

肝硬変症156例の全身血行動態を検討し，その意義を 考案した。その結果, (1)肝硬变症は hyperdynamic state を呈するが，これはは全身への酸素供給を增加さ せ，酸素消費量を維持するための代償としての意義が あった。 (2)肝障害が高度であるにもかかわらず hyper dynamic state を示さない症例は，手術後の合併症発 生頻度が高く，長期予後る不良である傾向を認めた。 (3)研变应に $3 \mu \mathrm{g} / \mathrm{kg} / \mathrm{min}$ の dobutamine を投与して 全身循環を hyperdynamic state とすると，肝動脈及 び門脈血流量が增加した，したがって肝硬変应手術例 に拈いて，同手術期に低浱度の catecholamine (dobutamine，dopamineなと）を投与して全身循環を hyperdynamic に維持することは重要な意義があると
考えられた。

\section{6. 血管造影による食道静脈瘠再発症例の検討} （衍後肝痘合併例について）

順天堂大学第 2 外科

$$
\begin{aligned}
& \text { 西村 泰彦，奥山耕一，中西亮 } \\
& \text { 览島 邦明，榛沢隆，木下 榮一 } \\
& \text { 深澤 正樹, 別府 倫兄, 二川 俊二 }
\end{aligned}
$$

1979年 9 月から1988年12月までに当科で行った経胸 食道離断術は354例で、このうち食道静脈瘤再発例は 33 例 (9.3\%) であった。これに対し，術後肝癌合併例で は43例中，食道静脈瘤再発例は，10例 $(23.3 \%)$ と高 率であった，そこで肝癌の諸因子と血行動態による食 道静脈瘤再発の要因の検討を行った，手術別では，全 例二期分割手術後の再発で，血管造影所見では，肝硬 変の進展による遠肝性血流の増掩が重要な要因上考之 られた。肝癌の諸因子では, A-P Shunt は認められず, 尰湯径, 肝内転移では有意差はなく門脈侵襲, 特に Vp3で食道静脈瘤の再発率が高かった，経胸食道離断

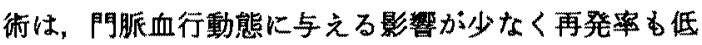
く有効な術式であると考えられた。

\section{7. 経皮経肝門脈造影と食道静脈㾇治療上の意} 義 九州大学第 2 外科

橋爪誠, 田上 和夫, 和田 寛也

経皮経肝門脈造影 (PTP) に上る食道静脈瘤血流 ターンを分類し，食道静脈瘤の治療上の意義について 検討したので報告する。

方法：症例は過去 2 年間にPTPを施行された食道 静脈瘤症例48で，食道下部の血流ハターンをすだれ型 と㮛棒型に分類し，臨床所見及び治療成績についてて比 較検討した。

結果：棍棒型はすだれ型に比へ肝機能不良例と吐血 既往例が多く，硬化療法後の小血管の出現は棍棒型で 有意に多かった．特に巨大暒棒型では硬化療法では治 瘾し難く，手術の適応と考学られた。

結論：食道静脈瘤の治療においては，血流バターン に応じた治療法の選択か重要である。

\section{8. 食道静脈瘤血液ガス分析の臨床的意義} 北里大学消化器内科, “外科，"*病理 國分茂博, 田辺聡, 石井公道 
柴田 久雄, 比企 能樹", 奥平 雅彦** 我々は46例の静脈瘤血液ガス分析により平均酸素分 王 $75.1 \mathrm{mmHg}$ ，平均酸素飽和度 $92 \%$ といら結果から， 静脈瘤には多量の動脈血の直接的流入があることを報 告した．今回は，硬化㞠法に上る血液ガス像の变化と， その出血予後等からこの静脈溜血液がス分析の臨床的 特に治療上の意義につき検討した。静脈瘤内血液を採 取し得た61例中，反復採取が可能であった19例を対象 とした，1回以上の硬化㞠法後に酸素分压が上昇した あのは10例，不変及び下降は9例であった，上昇した 10例中 8 例はその後出血無く経過良好であり，不変及 び下降の 9 例中 6 例は再出血をきたしており，静脈瘤 における動脈化は血行動態における佰常性の維持に関 わっており，治療中の指標にも成り得ると考えられた。

\section{9. 内視鏡的食道静脈瘤栓塞療法後の治療経過 観察指標としての血清胆汁酸}

筑波大学臨床医学系消化器内科, *同 外科 松崎 靖司, 田中 直見, 正田 純一 大营 俊明, 高瀬 䇌広*, 岩崎 洋治*

食道静脈瘤内視鏡的栓塞療法後の治療経過指標に血 清胆汁酸を利用した。栓塞療法を受けた肝硬変19例中， 治療後経過良好群（I）12例，治療後肝不全徽候を呈 した不良群（II）7例を対象とし，高速液っ口にて血 清胆汁酸分画測定を行った，治療前（前），後（後）の 総胆汁酸 (TBA) は, I で前： $65.4 \pm 22.1 \mu \mathrm{M}(\mathrm{M} \pm$ $\mathrm{SE}$ ), 後：23.4 $\pm 5.9 \mu \mathrm{M}$ と有意に低下した. IIで前： $33.5 \pm 4.9 \mu \mathrm{M}$, 後: $57.0 \pm 8.3 \mu \mathrm{M}$ と有意に増加した。 $\mathrm{CA}$ は I で前： $14.1 \pm 3.7 \mu \mathrm{M}$ ，後: $8.0 \pm 2.3 \mu \mathrm{M}$ と有

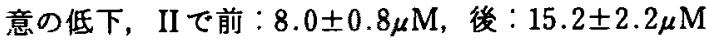
と有意の増加を認めた. CDCは I，II共に前後で変化 を認めなかった，C/CDC 比は，I，II共に前後で变化 を認めなかった，TBA 及び血清胆汁酸分画測定は食 道静脈瘤治療の経過観祭指標に有用と考えられた。

40. 超音波パルスドップラー法が診断, 治療上 有用であった肝動脈門脈瘦の 1 症例

東京慈恵会医科大学第 1 内科

$\begin{array}{llll}\text { 戸島恭一郎, 新井 } & \text { 豊彦, 空閑 } & \text { 和人 } \\ \text { 植松 } & \text { 幹雄, 山崎 } & \text { 一信, 樺 } & \text { 恵 } \\ \text { 石沢 和敬, 鬼沢 } & \text { 信明, 今井 } & \text { 深 } \\ \text { 重田 治男 } & & & \end{array}$

症例は68歳，女性．食道静脈溜破裂にて1988年11月 当科に入院した，超音波ハルスドッブラー法にて門脈
の拍動性逆流を認めたため訮動脈門脈瘦と缡断した。 1989年 2 月16日 TAE 施行したが，依然逆流がみられ たため，4月27日 TAE 再施行。その後出血はなく，眝 留していた腹水も消失したが，術後 2 週間より腹水胺 留を来した，超音波パルスドップラー法にて再度門脈 の拍動性逆流を認めた。 TAE は無奻と考え，1989年 7 月 1 日右中肝動脈結禁及び上腸間膜動脈からの血行遮 断，胃上部郭清，脾摘を施行した。超音波バルスドッ プラー法による血流測定は, 食道静脈瘤治療法の選択 と経過観察に有用であった。

41. パルスドプラ法を用いた門脈血流に対する 垔硝酸アミル負荷試験の開発一理論的評価一 山口大学第 1 内科

\begin{tabular}{lrr}
\multicolumn{1}{r}{ 田邊 } & 一郎, 沖田 & 極 \\
阿知須同病院内科 & 田邊 & 若子 \\
国立下関病院内科 & &
\end{tabular}

松田 彰史, 原田 俊則

方法：亜硝酸アミル負荷に対する門脈血流応答とし て，いわ的るWindkessel 理論を用いた循環制御論の 最す簡略化したモデルを考案し，動脈側にインバルス 入力を与えた場合の応答曲線をコンピュータにて解析 した.

結果：肝内血管抵抗が上昇するにつれて，門脈血流 の上昇の有意な低下と，立ち上がり時問の延長，回復 時間の遅延化などの現象をよく説明することができ， 肝内血管抵抗之門脈血流上昇の間には近似的な反比例 関保が示唆された，また，実際のデータと数值解析か らも上い一票をみた。，以上より，本法が肝内血流抵抗 の大小をよく反映することを示すととるに，慢性肝疾 患の門脈血圧上昇の過程を知る新しい手段として有用 であると考えられた。

42. パルスドプラ法を用いた門脈血流に対する 垔硝酸アミル負荷試験の開発一臨床的評価一 阿知須同病院内科田遗若子 山口大学第 1 内科 田 一郎, 沖田 極 国立下関病院内科

松田 彰史, 原田 俊則

目的：慢性肝疾患の肝内血管抵抗の非観血的測定老 目的に，門脈血流速度の応答をみた。

対象亚びに方法：健常者13例，慢性肝炎17例，肝硬 变27例を対象に，覀硝酸了ミルを吸入後 5 分間の門脈 
血流速度を測定し，上昇率，ビークまでの立ち上がり 時間 ( $\Delta \mathrm{t})$ ，前值にもどるまでの回復時間 ( $\left.\Delta \mathrm{t}^{\prime}\right)$ を比較 するとともにW index（上昇率/ $\Delta \mathrm{t}$ ）を設定した。

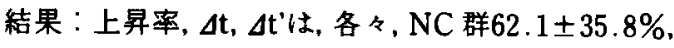

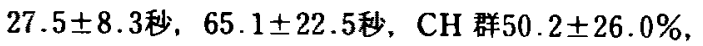
$37.7 \pm 21.2$ 秒， $84.2 \pm 38.9$ 秒， LC 群 $21.4 \pm 19.4 \%$, $68.8 \pm 42.1$ 秒, $1.76 \pm 76.9$ 秒で, W indexは2.47士 $1.97 ， 1.58 \pm 1.04 ， 0.36 \pm 0.15$ と応答の差は明瞭で, 旰内血管抵抗上昇の定量的な評価に有用と考えられ た。

\section{3. 超音波ドプラ法による左胃静脈血行動態の 検討}

千葉大学第 1 内科

$$
\begin{aligned}
& \text { 松谷 正一, 古瀬 純司, 有田 洋右 } \\
& \text { 大藤 正雄 }
\end{aligned}
$$

肝硬变症における左胃静脈血行動態の特徵を超音波 ドブラ法を用い検討した，対象は健常者40例，肝硬变 126例である. まず左胃静脈血流方向の検討では, 肝硬 变症でる食道静脈慮末発達拈よび一部の軽度発達例で は，健常者と同様に求肝性血流であったが，静脈瘤の 発達とともに左胃静脈血流は遠肝性へと変化した。 た左胃静脈血流速度については静脈瘤の形態が高度と なるに従って血流速度の有意な上昇みられ，硬化㞠法 の菜郕を選択する上で重要な所見と考えられた。次に ヘソプレッシン負荷の検討では，門脈幹の血流は施行 例全例で低下したか，左胃静脈では一部症例に不応例 がみられた。超音波トブラ法による左胃静脈血流計測 は食道静脈瘤に対する新たな血行動態診断法として有 用と考えられた。

\section{4. 肝内 A-P シャントを有する門脈血行動態 の把握と Color Doppler による display 虎の門病院消化器科}

村島 直哉, 竹内 和男, 池田 健次

熊田 博光, 中島 正男

対象：肝内肝動脈門脈霓 (A-P シャント) が画像診 断にて診断された16例（男13・女3例）を对象とした。 成因は，肝細胞癌 8 例・生針なとによる外価性 3 例で あったが残り 5 例は原因不明たった。食道静脈㴛は12 例 (75.0\%) に認められ，9例に硬化㞠法を施行した。 方法：血管造影は Seldinger 法にて，Bモード超音 波浼査は日立EUB40，Aloka SSD650，カラードプラ はHP77020AC/ARにて施行した。
成績：カラードプラ法は，門脈の逆流のカラー化に より A.Pシャントの存在診断が容易であった。シャン 卜点は乱流で示され，血管造影に優っていた。無症候 性の A-Pンャントの拾い上げも可能だった（３例）.

結語：肝内の血行動態の把握は門充症の研究に重要 でカラートブラ法は有用な手段になると思われた。

\section{5. 経食道超音波ドプラ法による奇静脈血流の} 測定

京都大学第 1 内科

$$
\begin{array}{lrrrr}
\text { 木村 達, 森安 } & \text { 史典, 川崎 } & \text { 俊彦 } \\
\text { 染田 } \text { 二, 王田 } \text { 尚, 山下 } & \text { 幸孝 } \\
\text { 小野 成樹, 暒村 幸三, 濱戸 } & \text { 教行 } \\
\text { 内野 治人 } & & &
\end{array}
$$

奇静脈血流は上行性短絡路血流の指標とされる。程 食道超音波ドプラ法を用いて計測した奇静脈血流イン デックス (AzVFI) を奇静肺血流の定量的指標とし， vasopressin 0.3 単位/分持続点滴負荷前後の变化を血 圧，脈拍，門脈，総肝動脈血流量の变化と合せて検討 しだ. Aloka 社製 SSD-350おょび経食道探触子(UST936W-5)を用い，奇静脈の頭側端にて血管径，FFTド ブラ信号を測定. FFTより求めた平均血流速から，血 管断面を円と仮定した AzVFI を算出。対象は食道静 脈瘤合併肝硬变 (LC) 10例, 慢性肝炎 $(\mathrm{CH}) 7$ 例. 成 績：前值ては，LC 群は CH 群に比し，奇静脈血管径， $\mathrm{AzVFI}$ ともに有意に高值を示した。負荷後の変化で は，門脈血流は全例著减 $(-58 \%)$ ．LC 群では奇静脈 平均血流速，AzVFI ともに15\%减少した。

46. バソプレシン投与が食道静腺瘦の血流速度 に与える影䈉一経食道ドップラ断層による分 析一

埼玉医科大学第 1 外科

$$
\text { 松本隆, 鉫柄 稳, 駒崎 敏郎 }
$$$$
\text { 尾本 良三 }
$$

経食道ドップラ断層法を用いて、パップレシン投与 前後で，食道静脈瘤の平均血流速度 $(\mathrm{V} \cdot$ mean $)$ 及び 脈管径を測定した，対象は16例の肝硬変患者で，内視 鏡的に静脈瘤を有するすのは15例で，10例に何らかの 治療がなされ，一方 6 例は未治療群であった。

ヘンプレシン投与前後で眽管径は有意な变化を認め なかった，一方静脈瘤の V・meanは，投与前が15.4士 $6.6 \mathrm{~cm} / \mathrm{sec}$ であったが， パンブレシン投与によって有 意に减少し， $8.6 \pm 4.7 \mathrm{~cm} / \mathrm{sec}$ となり，平均减少率は 
$43 \%$ あった。

非侵襲的な，経食道ドップラ断層法は，食道静脈瘤 の治㞠効果判定において，有用な検查法になるものと 思われた。

\section{7. 超音波内視鏡による食道静脈瘤流入路流出 路の検討}

東京医科齿科大学第 1 外科 中村 宏, 开上 晴洋, 五関 謹秀 河野 辰幸, 下重 勝雄, 遠藤 光夫

食道静脈瘤の血流流入路，流出路を知ることは治療 上重要であるが, 内視鏡による粘膜面観察や血管造影 の 2 次元的解剖からだけでは困難な点がある.我々は 経腹的直達手術を行った16例の食道静脈瘤症例におい て術中術後に超音波内視鏡 (EUS： Olympus GF. UM2, 7.5MHz, ラジアル型)の連続観察を行った. 壁外血行の観察により, 食道静脈瘤への流入血管は左 胃静脈, 短胃静脈でありそれぞれ小弯側, 大弯側の胃 壁内血管に注ぐ. 傍食道血管の分布は最高でもEGJ り口側 $7 \mathrm{~cm}$ までである。食道静脈瘤の流出血管として は主に奇静脈弓のレペルであることが推測された。 EUS の側副血行路観察は, 治療法の選択, 各種治療法
の効果判定に有効と思われる.

48. 門脈圧元進症における血行動態の検索と治 㬌法の選択

\section{東京慈恵会医科大学第 2 外科}

$$
\begin{array}{lrrr}
\text { 稲垣 芳則, 関口 } & \text { 更一, 岩猗 責 } \\
\text { 石井 堆二, 佳野 勝英, 恩田 啓二 } \\
\text { 中村 純太, 中里 } \\
\text { 中雄一, 木村 恵三 } \\
\text { 実, 青木 照明 }
\end{array}
$$

教室では門亢症の治療に際し各種血行動態の検索を 行っているが, 主として肝静脈血 $\mathrm{ICG}_{\mathrm{R} 15}$ と末梢血 $\mathrm{ICG}_{\mathrm{R} 15}$ の比較により肝外倒副路の程度判定を 3 型に分 類し手術, EIS の選択を行っている. その結果, 側副路 の良く発達したIII型はEISに著効を示し，食道静脈瘤 が主な側副路であるI型は手術療法が必要であるとの 結果を得た。各型の血流量を超音波ハルスドップラー 法で検討した結果、門脈血流量くSMVF+SVFであり III型はPVFに対するSVF の関与は低く，肝外短絡率 は増大していた，手術, EIS 後の血流変化は前者は血管 郭清により長期にわたり PVFの增加があり EIS 後は I 型で同様の結果を得た.

\section{III. その他}

49. 胃全摘術後静脈瘤出血に上腸間脈静脈枝 一腎静脈吻合術を施行した 2 例の経験

新渴大学第 1 外科, 信楽園病院外科* 佐藤 泰治，塚田 一博，中平 啓子 大谷 哲也, 杉本不二雄, 内田 克之 白井 良夫, 長谷川 滋, 吉田 奎介 武藤 輝一，清水 武昭*

胃全摘術後の静脈瘁出血に対し, 腸間膜静脈枝一腎 静脈吻合術を施行し持続的止血が古られた 2 例を報告 する. 症例 $1 ， 46$ 歳男性，IPH，他院で11年前に食道静 脈撚に対して胃全摘術が行われた。吊り上げ腸管の血 行遮断や硬化療法では持続的止血がえられず，腸間膜 静脈枝一左腎静脈吻合術を施行した。㭪後 4 年 7 月筋 萎縮性側索硬化应で死亡. 剖検によりシャントの開存 が認められた。症例 2，53歳女性，IPH, 胃癌で胃全摘 術後 1 年 4 力月で出血. 硬化療法を 6 回綝り返すも再 出血した.PTPで静脈瘤に流入する怒張した腸間膜静 脈を認めた。腸間膜静脈枝一左卵单静脈吻合術を施行
した. 術後約 3 年の現在再出血はない.

50. 代用血管を用いて左胃静脈，下大静脈吻合 術を施行した先天性門脈閉塞症の1例 名古屋市立大学第 1 外科

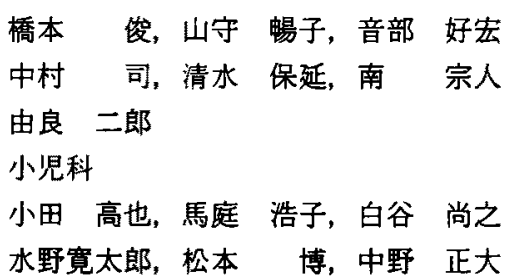

先天性門脈閉塞症による門脈王穴進症の治療とし て，代用血管を用いて門脈，下大静脈シャント術を施 行し有効であったので報告する，应例は 1 藏男胃で フォロー四徵症を合併し，主訴は大量の下血であった。 血管造影により門脈本幹の閉塞と, 全門脈血が左胃静 脈から噴門周囲，内胸静脈を介し上大静脈に流入する 所見を得だ。サントは $\phi 6 \mathrm{~mm} の$ Gore-tex ${ }^{\mathbb{R}} 6 \mathrm{~cm}$ を 用いて左胃静脈，肝下部下大静脈間に括いた。術後食 
道静脈瘤の軽快が認められた。

\section{1. 肝細胞癌切除症例における食道静脈瘤の治 療成績}

北海道大学第 1 外科

小笠原和宏，宇根良衛，中島保明

佐藤 直樹，長㴊 英介，田村元

神山 俊哉, 内野 純一

最近10年間の教室における肝細胞癌切除症例171例 中, 食道静脈瘤を合併していた23例（5ち 1 例は再切 除）を対象として，食道静脈嘴の治療成績について検 討した. $\mathrm{C}_{\mathrm{B}} \mathrm{RC}(+)$ または $\mathrm{C}_{\mathrm{B}} \mathrm{RC}(-) \mathrm{F}_{2}$ 以上の 4 例 に対して肝切除前または同時に直達手術を施行, 術後 出血はなかったが，1例に静眽瘤の再発をみた。ICG 15分值20\%以下で HrS 以上の肝切除可能例では直達 手術の併施子可能之考えられた。 また， $\mathrm{C}_{\mathrm{B}} \mathrm{RC}(+)$ 群 5 例中 2 例に術前内視鏡的硬化療法（EIS）を施行し， 静脈瘤の再発はみていない，両者とも破裂出血予防に 有用であった，直達手術の并施は，適応を選ぶことに より，有用な方法となりうると考えられた。

\section{2. 肝細胞癌合併食道静脈瘦症例の検討}

日本大学第 3 外科

$\begin{array}{rrrr}\text { 高野 } & \text { 靖悟, 手島 洋一, 関 } & \text { 訓芳 } \\ \text { 鉿木 } & \text { 武樹, 大塚 } & \text { 善久, 頁田 } & \text { 清美 } \\ \text { 村山 } & \text { 公, 佐藤 } & \text { 博信, 田中 } & \text { 隆 }\end{array}$

肝細胞癌合併食道静脈瘾において，肝細胞癌に対し て治療を行ったのは13例で，2 例に自然破裂症例を認 めて招り,これらの症例には肝動脈結禁術, 肝動脈結 慗術十エタノール注入を行った。肝切除は 5 例に施行 したが，すべて亜区域切除以下の術式であった， $F_{2}$ 以 上， $\mathrm{RC} \oplus$ の Risky Varix は 7 例、53.8\%であり13例 中，12例の食道静脈瘤に対して内視鏡的硬化療法 7 例 R. Hassab's 手術を 3 例に，内視鏡的硬化㞠法十 Hassab's 手術 2 例に施行した，予後をみると，13例中 3 例は肝細胞癌治療後 2 年 3 力月を最高に生存中であ るか，他は全て肝不全死，癌死，術後急性心不全死し たか，食道静脈瘤からの出血死は認めず，内視鏡的硬 化療法の有用性が示㗪された。

53. 肝硬変患者にみられた自然発生的脾盅, 胃 骨短絡についての臨床的検討

北海道大学第 3 内科

林下 尚之, 目黑 高志, 吉田 純一
斉藤 雅雄, 松嶋 喬, 宮嵭 保

今回，我々は肝硬变患者を自然発生的脾腎，胃腎短 絡の有無により 2 群に分け，胃食道静脈瘤の内視鏡所 見とその他の種々の臨床的所見，臨床症状の間の関釈 について検討したので報告する。対象：1983年 1 月か ら1989年 6 月までに当科隹入院した肝硬変患者113例 （内43例は肝癌合併例)を対象とした，結果：脾腎，胃 腎短絡は腹部 CTscanあるいは血管造影により13例 にみられた。内視鏡所見上，短絡例では非短絡例に比 べ，食道静脈瘤の程度はより軽い傾向がみられた，胃 静脈瘤は短絡例の内 9 例にみられた。臨床症状では， 短絡例の内 4 例に肝性脳症を認めた。結語：これらの 結果より, 自然発生的脾緊, 胃腎短絡が臨床所見叉臨 床症状に密接に関連している可能性が示唆された。

\section{4. 門脈圧え進症に対する Nitroglycerin 投与} の検討

久留米大学第 2 内科

野口 秀裁, 下津浦康裕, 永田一良 平井 賢治，豊永 純，谷川 久一

同第 1 外科 山名 秀明，掛川 暉夫

同 救命救急センター 加来 信雄

目的：門脈圧六進症に対して Nitroglycerin(GTN) 投与の効果について検討した。

対象・方法：食道胃静脈瘤破裂にて入院中の25例を

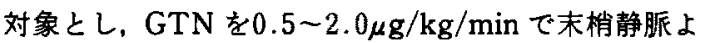
り持続注入し，経皮経肝的門脈造影下に門脈圧，血圧， 脈拍数を释時的に湘定. 又内視鏡所見の变化について 倹討した。

成績：1）GTNは門脈王降下作用を示した．2） Major shunt 発達例は，末発達例と比較して門脈圧が 有意に低下するが，平均血圧及び脈拍数には差がな かった.3）内視鏡的に明らかな胃粘膜発赤所見の改善 を示した例を認めた。

結語：GTN 投与は門脈正降下作用を示し，出血性 胃炎の改善に臨床応用が期待された。

55. 門脈圧元進症モデル犬を用いた Somatostatin と Somatostatin analogue(SMS 201995）の門脈血行動態に及ほす影響

昭和大学第 2 内科 米山啓一郎，桶口 健一，加藤 和夫 橘とも子, 高橋正一郎, 竹内 治男 小貴 誠，八田 善夫 
Somatostatin とその analogue (SMS 201-995)の門 眽及び全身血行動態におよばす影響を総胆管結禁によ る門え症モデル犬を用い検討した，両薬郕は，正常犬 及び門穴症犬ともに bolus injection で門脈血流量・門 脈王を減少後増加させる2 相性変化を示し，全身血流 は初期に末梢血管抵抗の堌大を示したが，門穴症犬で はその作用が減弱していた。閃脈血流減少作用の持続 には, continuous infusionが必要であったが, somatostatinは中止直後より増加が認められ, analogue は中止後60分まで减少していた. Somatostatin analogue は somatostatin K比し作用が強力かつ持続 性で，両者には作用機序に若干の差があるものと思わ れた。

\section{6. 門脈圧元進症における胃壁循環艺進状態と} 膵グルカゴン

\section{大分医科大学第 1 外科}

吉田 隆典, 御手洗義信, 中島 公洋 吉村 高尚, 長峰 健二, 金島 良一 小林 迪夫

門脈圧亢進症の胃壁循環穴進状態について，その成 因として膆グルガンに注目し，検討を加えた。門六 症30例抗よび対照12例について，水素ガスクリフラン ス法により胃粘膜，粘膜下血流を測定し，膵クルカゴ ンは二抗体法 RIA により定量した。手術を行った門え 症16例では，術中，末梢動眽（A)，左胃静脈（LGV）

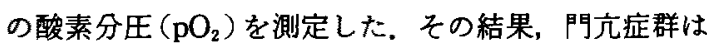
対照群に比し，有意の胃粘膜血流低下，粘膜下血流増 加を示した．脺グルカゴンは，胃粘膜血流とは負の相 関を，胃粘膜下血流とは正の相関を認め，さらに $\mathrm{pO}_{2}$ $\mathrm{LGV} / \mathrm{pO}_{2}-\mathrm{A}$ と正の相関を示した. 以上から, 膵グル コンン，門脈圧え進症における胃壁循罟え進状態発生 と密接な関保にあるるのと推定された。

\section{7. 門脈圧方進症における急性胃粘膜病変の成 因に関する実験的検討 \\ 杏林大学第 1 外科}

千葉 敦, 北島 政樹, 中島 正暢

検見崎博樹，立川軼

門脈王六進症に胃粘膜病変が高頻度で合併すること はよく知られている。.今回, 非肝障害性門脈圧元進症 ラットモデルを作製し胃粘膜病変の成因に関し検討を 行った。ウイスター系雄性ラットを用い門脈本幹の㹟 窄を作製し生体ラットでの食道, 胃内視鏡検查, 摘出
胃の肉眼所見，門脈王測定，胃粘膜血流量測定および 肝機能検查を含めた血液生化学の測定を行った，本実 験のモデルにおいて食道静脈瘤, 胃粘膜病变を観察し 得た。胃粘膜病変の成因として胃粘膜微小循環障害に 伴う胃粘膜防御機構の破綻が想定された。本実験モデ 儿は肝障害をさたすことがなく肝疾患に見られる種々 の障害による影䇾を受けず，門脈王え進症における胃 粘膜病変の成因の検討に有用と思われた。

58. 門脈圧え進症状を初発とする原発性胆汁性 肝硬变 (PBC) の病理学的検討

聖マリフンナ医科大学病理

$$
\begin{array}{lll}
\text { 東 永誠, 真坂 彰, 中西 千尋 } \\
\text { 丸山 哲生, 前山 史朗, 打越 敏之 }
\end{array}
$$

目的：PBCで,病変が早期にもかかからず食道静脈 瘤破裂を初発症状とする症例がみられた。今回，上記 の門六症を示した PBC 4例（Scheuer stage II）の病 理組織学的検討を行った。対象及び方法：対象は, 50〜66葴のいずれる女性 4 例で IPHないしは LCの 診断のもとに, 脾摘 (1症例を除く) 食道離断術, 肝 生娭が施行され，連続切片を作成し組織学的検討を 行った。

まとめ：中等大門脈域の形態は類円形を示するの と，星茫状に不規則な稩胞堌生を示するのとに大別さ れ，多くの拡張した小脈管叢が見られた。 又, 門脈域 内, 或いは辺縁, 更に小莱内に異常血行路が認められ た. 早期の PBCです組織学的にIPH と同質の变化が みられその関連性に興味がもたれた。

59. 門脈圧え進症におけるすだれ状血管走行部 の変化

*久留米大学第 1 病理, **同 第 2 内科

荒川 正博, 鹿毛 政義", 大久保和典

角野 通弘, 并上林太郎, 豊永 純**

門脈圧穴進症におけるすだれ状血管走行部の変化を 明らかにするため，30例のゼラチン添加バリウム注入 例を用いて形態学的・組織計測学的な検討を行った。

1. 門脈殴六進症が進むにつれ, 粘膜下層を走行する血 管が增えるが，このほとんどは粘膜筋板の状態から粘 膜固有層の血管であることがわかった，2，すだれ状 血管走行部では粘膜固有㒶を同じ程度の大きさに搪張 した静脈が全周性にみられるのにいわゆる静脈瘤では 粘膜下層を $3 ー 4$ 本の抎張，蛇行した静脈が存在し， その血管走行が大いに異なる．3．すだれ状血管走行 
60. 門脈循環から眺めた各種衙式の検討 札幌通信病院外科

磯松 俊夫, 杉井 重雄, 池田 浩之 高木 良三

今回検討の対象之なった症例は，肝硬变19, 肝外門 脈閉塞 5, 特発性門脈王六准症 1 で，治療法別内訳は 硬化療法 5 , 遠位脾腎静脈吻合 10 , 直達療法10である。 血行動態からみて食道静脈瘤型, 胃静脈瘤優位型, 胃静脈㿔型に分けられる。これは側副血行路の形成如 何に上るるので，術前にそれを認識しておくことは術 式選択の上で必要である，そのために腹腔動脈・上腸 間膜動脈左胃動脈造影は必碂で，術式の最終決定にあ たり胃壁静脈・門脈系の压測定・造影も必要となる。 手術は直達療法であれ遠位脾堅静脈吻合であり，人為 的に静脈癉への血流を他に転换し静脈瘤の消失をはか るもので，それが永続するか否かは，根幹䐘器である 肝の循環動態にかかっている。この術前予測に閉塞肝 静脈造影は重要である.

\section{1. 血行動癿からみた治療法の選択} 東京大学第 2 外科

$\begin{array}{lrrr}\text { 三條 健昌, 今村 } & \text { 宏, 野村 } & \text { 幸博 } \\ \text { 平田 勝, 皆川 } & \text { 正己, 橋本 } & \text { 雅司 } \\ \text { 柴崎 } & \text { 正幸, 小山 } & \text { 広人, 針原 } & \text { 康 } \\ \text { 大友裕美子, 大橋 } & \text { 一雅, 川崎 } & \text { 誠治 } \\ \text { 出月 康夫 } & & & \end{array}$

門脈王亢進症は, 原疾患の natural history に予後は 大きく左右される。ささらに門脈圧六進状態が維持され るには，途中経路の門脈采の血流障害に加えて，側副 血行路の血管抵抗，門脈系に流入する血流量の増大も 関連し，食道静脈瘤は，門脈圧の上昇に伴って発達す る多数の側副血行路の一つであることから，食道静脈 瘤は，他の側副血行路の消長の影牟も受ける. 亦, 食 道静脈溜の存在が、即治療の対象となる出血に結びつ かない。このよ5に，一つの病態に多数の要因が複雑 に絡み合っているので，食道静脈瘤治㞠の適心にあ たっては，血行動態の検討が必須のものとなる. 今回, 術前，術中，術後の血行動態と治療法の選択について
検討したので報告する.

\section{2. 左胃静脈下大静脈吻合術長期開存のための 血行動態の検卖}

$$
\begin{gathered}
\text { 大分医科大学第 } 1 \text { 外科 } \\
\text { 御手洗義信, 吉田 隆典, 中島 公洋 } \\
\text { 長峰 健二, 金 良一, 小林 迪夫 }
\end{gathered}
$$

教室での左胃静脈下大静脈吻合術施行例は34例であ る. 5ちシャントの晚期閉塞例 (A 群) とシャント開 存を確認し長期にむ追加治療を要しなかった完全有効 例（B 群）とを対比し検討した．1．原疾患ならびに街 前の肝機能検査には 2 群間に差はなかった。 2 . 術前の 血管造影上, 左胃静脈径は，A 群が B 群に比し太い傾 向にあった，左胃静脈血流方向では，B群はより hyperdynanic な血流動態を示した，3，内視鏡による 㥜壁小循環の测定で，B 群はより hyperdynamic な血行動熊を示した。. 4.術中シャント流量・門脈王は， 2 群間に有意差はなかった．5. 摘出脾重量は，A 群は $\mathrm{B}$ 群に比し重い傾向にあった。以上より,シャントの 長期的な維持には，門脈采及び胃壁の hyperdynamic state の関与が重要であると考えられた。

\section{3. 硬化療法中の造影所見と治療上の意義 東京医科齿科大学第 1 外科}

$$
\begin{aligned}
& \text { 井上 晴洋, 中村 宏, 村瀨 尚哉 } \\
& \text { 河野 唇幸, 五関 謹秀, 竹下 公矢 } \\
& \text { 遠藤 光夫 }
\end{aligned}
$$

食道静脈瘤硬化療法に際し，基本的に $5 \%$ EO の血 管内注入法を施行している，そこで硬化剂に造影剂 Iopamidol を添加し造影剤濃度を46\%にしたものを用 い，血管内注入時の varicography について検討した。 なおわれわれは細い静脈瘤に対しても血管内注入を行 うため,「透明チューブを用いた陰圧下穿刺法」を施行 している，その結果，典型例では，最初に太く蛇行す る varicography が $2 \sim 4$ 回得られ，残った細い静脈 瘤に対してもさらに血管内注入を括こならと「下部食 道壁を取り巻くような網目状の造影所見（finenetwork pattern)」が描出され，静脈瘤は完全消失す る.したがって，高賴らの栓塞療法に加え，fine- 
network pattern を描出することが血管内注入法によ る治療の最終目標であると考えている。

\section{4. 食道静脈瘤に対する超音波内視鏡（EUS） の意義}

$$
\begin{aligned}
& \text { 日本大学第 } 3 \text { 外科，“同 放射線科 } \\
& \text { 大塚 善久，村山公，佐藤 博信 } \\
& \text { 河口 忠彦, 頁田 清美, 鈴木 武樹 } \\
& \text { 田中 隆，山口 哲司* }
\end{aligned}
$$

昭和58年以降食道胃静脈放に対して，当教室では内 視鏡的硬化療法を主体に Hassab 手術を付加してき た。従来は経皮経肝門脈造影（PTP）に上り手術適応 を决定していたが，PTP は苦痛が多く侵裝も過大であ ク，頻回に行える検査法とはいえない，一方EUSは手 技が簡硬で何回でる行ら事が可能である.EUSの胃体 部から窮蕯部での走査では，左胃静脈系，短胃静脈系 からの供給路の判別が可能であり，胃静脈瘤の判定も 容易である..食道での走查では食道静脈瘤の描出の他 に傍食道静脈，奇静脈径の測定も容易である。現在で は傍食道静脈の発達した症例に対し Hassab 手術を付 加して扰り，EUSは血行動態の判定はもとより手術適 応の決定にも有用であると考劣る。

\section{5. 門脈圧元進症治療における超音波ドップラ} 法の意義

兵庫医科大学第 2 外科

$$
\begin{aligned}
& \text { 高木 一光, 芦田 寛, 福田 } \text { 正春 } \\
& \text { 西岡 昭彦, 橋本 直樹, 琴浦 } \text { 義尚 } \\
& \text { 石川 羊男, 宇都宮譲二 }
\end{aligned}
$$

超音波ドップラ法による門脈正六進症治療の評価を 試みた。遠位脾腎静脈吻合改良術式 (DSRS+SPD)で は，門脈血流量は術前に比し街後减少を認めるが，释 時的な低下は認めなかった，脾静脈血流量は術前後を 通じて匡は定の流量が得られた。 巨脾群と非巨脾群 に分類すると，術前に比し門脈血流量は巨脾群で術後 有意な減少を認めたが，非巨脾群では認めなかった。 DSRS では，DSRS+SPD，直達術と比べ術後門脈血流 量の低下は明らかであった，更に，直達術に後再発， DSRS 後, 内視鏡的硬化療法後症例では, 血行動態的 には興味ある結果を得たので報告した。

\section{6. 食道静脈瘤治療前後の各種血流測定の意義 要知医科大学第 1 外科}

黑田 博文, 田中一正，小林 秀雄
坂野耕司，神谷去，田中信臣

長谷川 誠, 鬼頭 正人, 河合 庸任 竹重 言人, 山本 貞博

私共は，食道静脈瘤に対する治療として直視下胃上 部切除術を基本とし，治療前後にレーザードップラー 法による食道胃粘膜血流，持続的局所熱希积法による 奇静脈血流などを測定し治療奻果の判断材料としてい る。

食道粘膜血流量は胃上部切除術，硬化療法ともに治 療後有意に減少し，胃粘膜血流量に变化はなかった。 奇静脈血流量は術後减少傾向を示したか，排出血路上 しての血流は温存されていた。術中の肝組織血流量は 良好に維持された。 以上，胃上部切除術の治療効果と 合理性を今回の検討から再確認した。

\section{7. 門脈血行動態より見た術前PTP の有用性 大阪市立大学第 1 外科}

西野 裕二, 小野田尚佳, 久保 陖彰

東楖 杏一, 竹内 一浩, 吉川 和彦

山下 隆史, 梅山 整

門脈圧六進症73例に対し释皮程肝門脈造影 (PTP) を施行した。側副血行路は68例，93.2\%に認められ， 左胃静脈を介し食道静脈瘤 (EV) へ向からものが最も 多く，EVへ向かわない側副血行路も認められた。

$\mathrm{EV}$ 一向か5側副血行路の発達が認められた症例 や，吐血歴のある例で門脈圧が高かった。

術前後でPTPを施行しえた13例では1例を除き手 術後の門脈圧は平均 $73.8 \mathrm{mmH}_{2} \mathrm{O}$ 低下していたか，術 後門脈圧の上昇が認められた胃静脈瘤の 1 例は左堅静 脈, 傍脐静脈への短絡路が遮断され, 術後 EV の発生 がみられた。

以上のことょり術前のPTPは，側副血行路の同定， ならびに食道胃静脈憈に対する直達手術に際し，温存 すべき側副血行路の判定に有用であると考えられた。

\section{8. 食道静脈瘤硬化痖法における経脾的 RI 門} 脈造影法の意義

奈良県立医科大学第 3 内科

$$
\begin{aligned}
& \text { 本田 泰啓，松村 雅彦，小泉 雅紀 } \\
& \text { 小葛 秀之, 森村 昌史, 長本一成 } \\
& \text { 福井博, 过井 正 }
\end{aligned}
$$

食道静脈瘤硬化療法 (EIS) を施行した肝硬变患者21 例に対し，EIS 前, EIS $1 ク$ 一終了後(EIS 後) 2 週, 4 週，12週に経脾的 RI 門脈造影法 (SSP) を行い，画 
像の変化，上行性血流量及び肝血流量 (HBF) の変動 につき検討した，21例中11例で画像の変化を認め，5 ち 6 例に EIS 後上行性血行路の消失を認めた， 5 例で は EIS 後新たな血行路が描出されるようになった。 上 行性血流量の経時的変動からみて, EISの効果判定時 期は, EIS 後 4 週が妥当であると考えられた。 EIS 前で 上行性に加え下行性血行路を有した場合, HBF は肝 右葉で有意に増加した。 以上, SSPはEISによる門脈 の循環動態の変動を視覚的かつ量的に把握でき, EIS 治㞠上有用な検査法と考える。

69. 腹腔動脈, 上腸間膜動脈造影から見た, 直達 術術後の静脈瘤再発形式の検討

聖マリアンナ医科大学第 1 外科

萩原優, 酒井昌博, 中野末広 $\begin{array}{llrr}\text { 長岡 } & \text { 至朗, 猪特 } & \text { 次郎, 得平 得彦 } \\ \text { 吉田 } & \text { 紘一, 窪田 偻, 山口 } \\ \text { 渡辺 弘 } & & & \end{array}$

食道静脈瘤に対する奻果を術前の腹部血管造影の所 見より，術後の内視鏡による成績と対比させた，対象 症例は直達術が施行された122例中，70例が適応となっ た。検討項目の, 䀒動脈, 脾動脈, 門脈、門脈径、脾 重量に関しては術後成績と相関がなかった，腹腔動脈 と上腸間膜動脈の静脈相より, 左胃静脈之短胃静脈の 造影の有無により, 各々 4 型に分類し治療効果と対比 した．結果は腹腔動脈之上腸間膜動脈の両方からしか む左胃静脈之短胃静脈が同時に造影されている症例で は 5 例中 4 例に再発が見られ, 直達術後の再発では, 胃の小弯と大弯に沿って上行する血管が多い程再発し やナい傾向があった。 